Annals of Warsaw University of Life Sciences - SGGW

Land Reclamation No 46 (4), 2014: 337-351

(Ann. Warsaw Univ. Life Sci. - SGGW, Land Reclam. 46 (4), 2014)

\title{
The possibilities of wetland preservation within the depression cones of limestone and marl mines at Leśnica-Małogoszcz and Bukowa in the circumstances of deepening the level of exploitation
}

\author{
TADEUSZ CIUPA, ROMAN SULIGOWSKI
}

Department of Hydrology and Geo-Information, Jan Kochanowski University in Kielce

\begin{abstract}
The possibilities of wetland preservation within the depression cones of limestone and marl mines at Leśnica-Matogoszcz and Bukowa in the circumstances of deepening the level of exploitation. As a result of enlarging the depth of exploitation of raw rock material deposits of marl and limestone at Leśnica-Małogoszcz (Przedborsko-Małogoskie Range - Świętokrzyskie Voivodeship), initially to the level of $+215 \mathrm{~m}$ a.s.l. and then $+200 \mathrm{~m}$ a.s.l., a mine depression cone will develop, which may threaten the existence of wetlands included in the Natura 2000 network. The wetlands are present in the pre-gorge section of Łososina river flowing through Grząby Bolmińskie and Gnieździskie Hills, at the mouth section of its hydrometrically ungauged tributary - the Wrzosówka river. In the study there has been demonstrated the possibility of preserving the current state of moisture content of the habitats which exist here, taking into account the quantitative characteristics of the components of water cycle and morphological conditions. The analysis of water resources has shown that under the conditions of a functioning mine depression cone, they will be sufficient to supply endangered wetlands and enable their irrigation. The solutions of an ecohydrological character have also been put forward which would compensate the loss of water in the area within the open-pit mine depression cone. This would require the construction of dams (e.g. artificial rapids) in the Wrzosówka river bed and a system of ditches at the bottom of its valley.
\end{abstract}

Key words: open-pit mine, mine depression cone, wetlands, Małogoszcz

\section{INTRODUCTION}

Open-pit mines affect the aquatic environment not only within the area of exploitation, but also, in an indirect way, in the area of mine depression cones, which surface area may considerably exceed the area of a mining excavation.

The reference sources are dominated by studies on the influence of open-pit mine exploitation of underground lignite deposits on groundwaters and surface waters over large areas in the region of Konin, Turek, Bełchatów and Turoszów (i.a. Choiński, 1978, Wilk, 1990, 1999, 2003, Maksymiuk, 2002, Wilk and Bocheńska, 2003, Wilk and Kulma, 2004, Jończyk et al., 2005, Motyka et al., 2007, Stachowicz and Szczepiński, 2007). Rock materials mines, in turn, generally cause local changes in the aquatic environment. In most cases, the exploitation of these deposits is held above the groundwater table or is performed in impermeable rocks, without causing the formation of large cones of depression. In Poland, the biggest transformations of this type occur in Świętokrzyskie region, especially in the so-called Białe Zagłębie, 
where the exploitation goes below the groundwater table (Szczepański, 1982, 1987, Herman et al., 1991, Biernat et al., 2004, Suligowski et al., 2009, Ciupa et al., 2011, Prażak, 2012). Therefore, in order to maintain the extraction process, an open pit dewatering is indispensable, which is an indirect result of the formation of cones of depression on the surface and the disappearance of hydrographic objects. Similar hydrogeological and hydrographic effects will presumably appear around other carbonate raw materials mines, i.a. Leśnica-Małogoszcz and Bukowa.

The open-pit marl and limestone mine of Leśnica-Małogoszcz, run by Lafarge Cement SA for the needs of Małogoszcz Cement Factory is located within Przedborsko-Małogoskie Range, in Świętokrzyskie Voivodeship. The current surface mining area is 297 ha, including excavation - 70 ha. Currently, the level of mining exploitation reaches here $+230 \mathrm{~m}$ a.s.l., but in the near future, the exploitation of raw rock materials is planned, first to the level of $+215 \mathrm{~m}$ a.s.l. and then $+200 \mathrm{~m}$ a.s.l. At the distance of approximately $5 \mathrm{~km}$ from the Małogoszcz Cement Factory in the NW there is a similar in size limestone mine at Bukowa (respectively: $3.49 \mathrm{~km}^{2}$ and $74.6 \mathrm{ha}$ ), where the exploitation of raw materials is implemented at similar levels. This property is managed by Lhoist Bukowa sp. z.o.o.

It is predicted that during the exploitation of carbonate rocks at the lower levels, the existing mine depression cones will deepen and widen, as the result of the need for mine dewatering: Leśnica-Małogoszcz and Bukowa. Locally, there will be a conjunction of the cones and this will cause cumulative effects in the natural environment, especially within the existing wetlands, along with valuable habitats (Dokumentacja hydrogeologiczna..., 2012a, b, Przemyski et al., 2012). Lowering the water abundance in the forest areas will be mostly noticeable in wetland and humid habitats, causing damage to the tree stand.

The aim of the study is to determine the hydrological effects associated with the development of the depression cone, resulting from extending the depth of mining of marl and limestone deposits in Leśnica-Małogoszcz and Bukowa areas, at wetlands located in the basin of the Wrzosówka river as well as presenting action proposals aiming at the preservation of the current state of moisture conditions of the habitats existing here, taking into account the quantitative characteristics of the components of the water cycle.

\section{MATERIAL AND METHODS}

A variety of methods, tools and research techniques of a local character have been implemented in the study (the elaboration of the existing archival and cartographic materials), as well as field and study. These works included:

- delimitation of the Wrzosówka river catchment including wetlands, on the basis of Digital Elevation Model; 
- cartometric analysis based on thematic maps in the scale of $1: 50000$ (hydrographic, sozological, geological), topographic in the scale of $1: 10000$ and orthophotomaps;

- determination of characteristic and inviolable flows as well as runoff using different methods from the ungauged Wrzosówka catchment - a description of the methods used are presented in the concluding part;

- proposals for measures aiming at maintaining the adequate moisture in the currently existing wetland areas of the Wrzosówka river valley, which may be found within the predicted mine depression cone.

\section{STUDY AREA}

The main object of interest are wetlands with their natural habitats located at the bottom of the Wrzosówka river valley (stream from Skorków), which in the predicted increase of the range within the depression cone around the mine in Małogoszcz may undergo drainage. The hydrological characteristics of these areas may not be limited only to the restricted range of the exploited deposit and the cone of depression, and should be carried out within the natural hydrographic units which are river basins. It is especially justified when the analysis of the aquatic environment is performed with the consideration of the balance recognitions.

For this purpose, the Wrzosówka catchment has been distinguished - the 4th order. The Wrzosówka stream of a length of $7.86 \mathrm{~km}$, an average slope of $0.26 \%$, flowing to Lososina (the 3rd order) at $8.2 \mathrm{~km}$ of its flow $(4.3 \mathrm{~km}$ above the water gauge IMWM in Bocheniec). Łososina forms here a gorge across Grząby Bolmińskie and Gnieździskie Hills, near the village of Zakrucze. Above the gorge the accumulative plains were formed, which are wetlands and recently superstructured biogenic mineral sediments (Sołtysik, 2002, Rodzik et al., 2008). At the bottom of the Wrzosówka river valley the existing wetlands also arose over morphological constrictions. In part, they are also subject to existing railway and road embankments (Fig. 1). There have developed valuable alder riparian forests and swamp forests over them, recognized as a priority in the EU Habitats Directive. This area is protected under the Natura 2000 network called Chęciny-Kielce Hills (PLH260041) and Konecko-Łopuszański Protected Landscape Area. The habitats protected here may, however, be at risk due to an expanding depression cone of Leśnica-Małogoszcz mine. Its area at the current level of exploitation $(+232.0 \mathrm{~m}$ a.s.1.) is $3.37 \mathrm{~km}^{2}$, and the planned +215.0 and $+200.0 \mathrm{~m}$ a.s.1. respectively 18.3 and $29.0 \mathrm{~km}^{2}$. The depression cone is expected to have an irregular shape, elongated in the NW-SE direction (Dokumentacja hydrologiczna..., 2012a). At the level of exploitation of $+215.0 \mathrm{~m}$ a.s.l. it will cover the towns of Leśnica, Zakrucze, the northern part of Małogoszcz and 


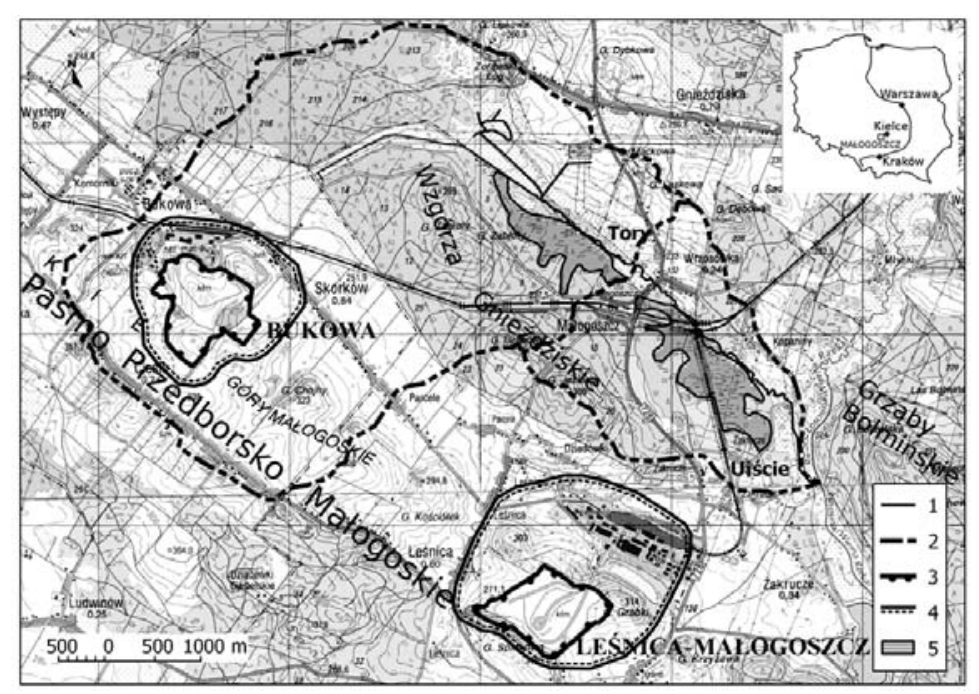

FIGURE 1. The location of wetlands in the Wrzosówka river basin (the section of Tory and Ujście), including the ranges of the depression cones caused by the exploitation of limestone and marl deposits of Leśnica-Małogoszcz and Bukowa. 1 - rivers, 2 - drainage divide, 3 - open pit, 4 - cone of depression in 2011, 5 - wetlands

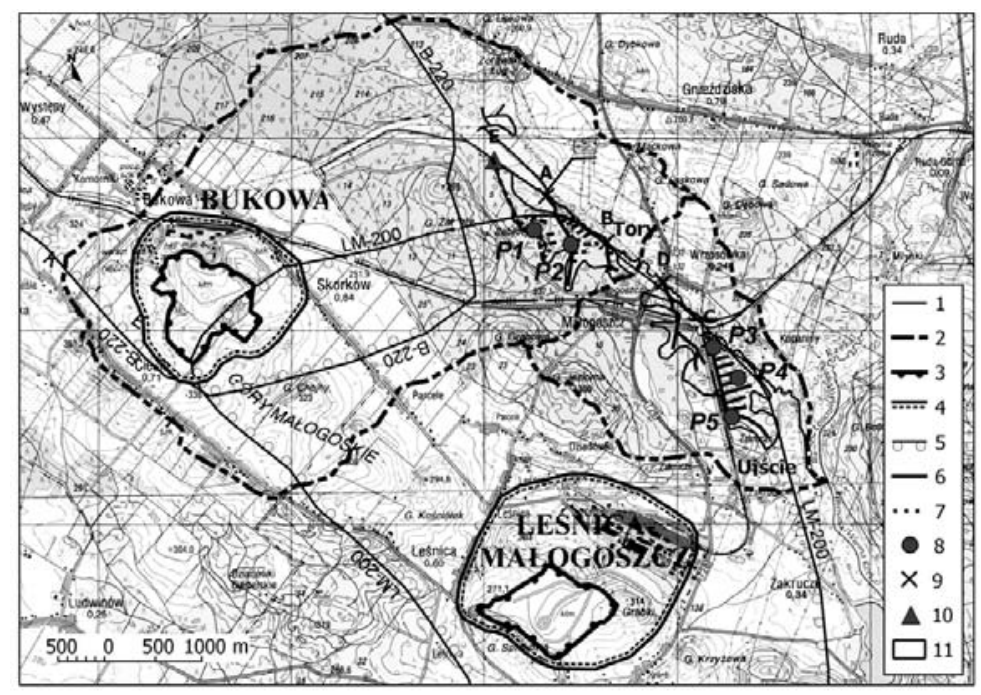

FIGURE 2. The suggested location of the thresholds-riffles and the ditches irrigating the wetlands with valuable natural habitats in the Wrzosówka river valley. 1 - streams, 2 - drainage divide, 3 - open pit, 4 - cone of depression in 2011, 5 - predicted cone of depression (LM-200 - Leśnica-Małogoszcz mine, exploitation at the $+200 \mathrm{~m}$ a.s.1., B-220 - Bukowa mine, exploitation at the $+220 \mathrm{~m}$ a.s.1.), 6 - suggested ditches irrigating during exploitation in the Leśnica-Małogoszcz mine at the $+215 \mathrm{~m}$ a.s.1., 7 - suggested ditches irrigating during exploitation in the Leśnica-Małogoszcz mine at the $+200 \mathrm{~m}$ a.s.l., 8 - piezometer, 9 - threshold-riffle during exploitation in the Leśnica-Małogoszcz mine at the $+215 \mathrm{~m}$ a.s.1., 10 - threshold-riffle during exploitation in the Leśnica-Małogoszcz mine at the $+200 \mathrm{~m}$ a.s.l., 11 - wetlands 
Parcele. At the level of exploitation of $+200.0 \mathrm{~m}$ a.s.1. the cone will approach to the village of the Wrzosówka in the north, Mieronice in the south, it will cover part of Łososina river valley and near Skorków it will connect with the cone created around Bukowa mine (Fig. 2).

Currently, the waters coming from the pit dewatering in Leśnica-Małogoszcz quarry are directed to the ditch escaping directly to Łososina. In turn, the waters from the pit in Bukowa are discharged through a ditch to the Wrzosówka river.

\section{RESULTS}

The runoff characteristics of hydrometrically uncontrolled streams are determined by indirect methods and empirical formulas (Byczkowski, 1996). Wrzosów$\mathrm{ka}$ is such a stream. For the purposes of hydrological analysis the catchment of the Wrzosówka river has been divided into two parts, i.e. the cross-section of Tory (near the village of Wrzosówka) - $18.44 \mathrm{~km}^{2}$, and the cross-section of Ujście $-23.23 \mathrm{~km}^{2}$.

Mean annual flow (SSQ) has been calculated using three methods: specific runoff, Iszkowski modified by Byczkowski and Punzet. The calculated values of both mean annual flow (SSQ) and mean of minimum annual flow $(S N Q)$ are similar (Tables 1, 2).

In order to know the annual regime of runoff, using the method of river analogy, the runoff and flow have been determined - average of minimal (respectively: $S N q$ and $S N Q$ ) of the Wrzosówka river in the cross-section of the Tory and Ujście (Table 3). The first one is associated with the underground runoff, the other - with the inviolable flow determined by Małopolska method.

In the annual cycle there are two climaxes of the Wrzosówka river un-

TABLE 1. The results of calculations of mean annual flow - SSQ of the Wrzosówka river

\begin{tabular}{|l|c|c|c|}
\hline \multirow{2}{*}{$\begin{array}{l}\text { Cross- } \\
\text {-section }\end{array}$} & \multicolumn{3}{|c|}{ Method } \\
\cline { 2 - 4 } & Specific runoff & Iszkowski & Punzet \\
\cline { 2 - 4 } & $S S q \cdot A$ & $0.0317 \cdot c \cdot P \cdot A$ & $21.576 \cdot P^{2.06} \cdot i^{0.065} \cdot N^{-0.044} \cdot A$ \\
\hline Tory & 99.6 & 99.2 & 89.3 \\
\hline Ujście & 125.4 & 124.9 & 110.8 \\
\hline
\end{tabular}

$S S q$ - specific runoff: $5.4 \mathrm{dm}^{3} \cdot \mathrm{s}^{-1} \cdot \mathrm{km}^{-2}$ - specific runoff from the Łososina catchment at the Bocheniec water gauge in period 1961-1995;

$A$ - the catchment area in the calculating cross-section: Tory $-18.44 \mathrm{~km}^{2}$, Ujście $-23.23 \mathrm{~km}^{2}$;

$c$ - runoff coefficient: 0.27 - weighted average (taking into account the physiogeographical characteristics of the catchment);

$P$ - average of annual precipitation total: $628.2 \mathrm{~mm}(0.6282 \mathrm{~m}$ according to Punzet model $)$ - area average of annual precipitation total in the Lososina catchment in 1971-1990;

$i \quad$-stream gradient: Tory $-0.00361 \mathrm{~km} / \mathrm{km}, \mathrm{Ujście}-0.00261 \mathrm{~km} / \mathrm{km}$; based on the analysis of the topographic map in scale of 1: 10000 ;

$N$ - coefficient characterizing the permeability of soils: Tory -48 , Ujście -42 ; using hydrographic map in a scale of $1: 50000$. 
TABLE 2. The results of calculations of mean of minimal annual flow - SNQ of the Wrzosówka river

\begin{tabular}{|l|c|c|}
\hline \multirow{2}{*}{$\begin{array}{l}\text { Cross- } \\
\text {-section }\end{array}$} & \multicolumn{2}{|c|}{ Method } \\
\cline { 2 - 3 } & Specific runoff & Byczkowski and Mandes \\
\cline { 2 - 3 } & $S N q \cdot A$ & $4.01 \cdot 10^{-11} \cdot(1+J e z)^{10.9} \cdot P^{3.8} \cdot D^{-0.032} \cdot A$ \\
\hline Tory & 51.6 & 42.4 \\
\hline Ujście & 65.0 & 51.1 \\
\hline
\end{tabular}

$S N q$ - average of minimal annual specific runoff: $2.8 \mathrm{dm}^{3} \cdot \mathrm{s}^{-1} \cdot \mathrm{km}^{-2}$ - values of average of minimum annual specific runoff from the Lososina catchment at Bocheniec water gauge in period 1961-1995;

Jez - rate of catchment pondage: $0.01 \%$ - the surface of existing water reservoirs in 2013;

$D$ - stream density in the catchment area: Tory $-0.57 \mathrm{~km} / \mathrm{km}^{2}$, Ujście $-0.65 \mathrm{~km} / \mathrm{km}^{2}$; based on the topographic map in scale of 1: 10000 .

Other explanations as under Table 1.

TABLE 3. Average of monthly specific runoff $-S N q$ and flow $-S N Q$ of the Wrzosówka river

\begin{tabular}{|c|c|c|c|c|c|c|c|c|c|c|c|c|}
\hline \multirow{2}{*}{\begin{tabular}{|l|} 
Cross- \\
-section
\end{tabular}} & \multicolumn{12}{|c|}{ Months } \\
\hline & $\mathrm{XI}$ & XII & $\mathrm{I}$ & II & III & IV & $\mathrm{V}$ & VI & VII & VIII & IX & $X$ \\
\hline \multicolumn{13}{|c|}{$S N q\left[\mathrm{dm}^{3} \cdot \mathrm{s}^{-1} \cdot \mathrm{km}^{-2}\right]$} \\
\hline Tory & 2.8 & 2.6 & 2.1 & 2.5 & 2.6 & 2.5 & 1.9 & 1.8 & 1.7 & 1.8 & 2.0 & 2.3 \\
\hline Ujście & 3.5 & 3.2 & 2.6 & 3.2 & 3.3 & 3.1 & 2.4 & 2.2 & 2.2 & 2.3 & 2.5 & 2.9 \\
\hline \multicolumn{13}{|c|}{$S N Q\left[\mathrm{dm}^{3} \cdot \mathrm{s}^{-1}\right]$} \\
\hline Tory & 64.5 & 59.6 & 47.9 & 58.4 & 60.2 & 57.2 & 43.6 & 41.2 & 40.6 & 41.8 & 46.1 & 52.9 \\
\hline Ujście & 81.3 & 75.1 & 60.4 & 73.6 & 75.9 & 72.0 & 55.0 & 51.9 & 51.1 & 52.7 & 58.1 & 66.6 \\
\hline
\end{tabular}

derground runoff observed: the first in November (Tory $-2.8 \mathrm{dm}^{3} \cdot \mathrm{s}^{-1} \cdot \mathrm{km}^{-2}$, Ujście $\left.-3.5 \mathrm{dm}^{3} \cdot \mathrm{s}^{-1} \cdot \mathrm{km}^{-2}\right)$, and the second in March (respectively 2.6 and 3.3). The lowest values were determined in July (Tory $-1.7 \mathrm{dm}^{3} \cdot \mathrm{s}^{-1} \mathrm{~km}^{-2}$, Ujście $\left.2.2 \mathrm{dm}^{3} \cdot \mathrm{s}^{-1} \cdot \mathrm{km}^{-2}\right)$. It follows that the underground runoff is much higher in the warm hydrologic season than in the cold season.

The results of flow calculations were compared with the results of measurements of flow using the propeller-type current meter in the Wrzosówka river at cross-section Ujście, taken during hydrographic mapping in July 2004 and 2013, during non-precipitation period, in similar hydrometeorological condi- tions. In 2004, the flow of $45 \mathrm{dm}^{3} \cdot \mathrm{s}^{-1}$ was documented (Biernat et al., 2004), and in $2013-43 \mathrm{dm}^{3} \cdot \mathrm{s}^{-1}$. It follows that the average of minimum flows in recent years remain stable here.

Average annual total runoff $\left(H_{c}\right)$, depending on the method used, in the Wrzosówka catchment varies from: 152.7 to $170.3 \mathrm{~mm}$ (Tory) and from 150.4 to $170.2 \mathrm{~mm}$ (Ujście). On the other hand, the average annual total underground runoff $(\mathrm{Hg})$ in the catchment area, depending on the method used, varies from 72.5 to $88.2 \mathrm{~mm}$ (Tory) and from 69.4 to $88.2 \mathrm{~mm}$ (Ujście).

The formation of a depression cone is always associated with a disorder of water relations in the area of its cover- 
age. Negative effects may be limited here, but it requires a number of activities, starting with the quantitative determination of hydrological effects. It is necessary, therefore, to suggest solutions of a ecohydrological character (including hydrotechnical engineering), which would compensate the loss of water in the area. Thus, the question arises whether there are sufficient water resources in the Wrzosówka catchment that could be used for the purposes of habitats irrigation and preventing their degradation. At the same time it should be emphasized that for the hydration of endangered habitats the water from the Małogoszcz mine is not expected to be used, because they are discharged into Leśnica steam, flowing directly to Łososina. The transfer of these waters to the Wrzosówka catchment would be very expensive and difficult from an organizational and technical point of view. In addition, the chemical composition of these waters would affect adversely protected natural habitats. An alternative for maintaining adequate soil moisture within the existing wetlands, but associated with incurring large expenditures would be to build a water intake from the Łososina river bed near the Wrzosówka river mouth and transfer the water through a pipe - installed in the bed zone, upstream to the places where main ditches originate, and from there by gravity - through the side ditches.

For the purposes of balance sheets, all the components of water cycle (natu- ral and anthropogenic) are compiled in the form of runoff using the formula:

$$
\Delta H=H g_{\mathrm{z}}+H p+H z-H n
$$

where:

$\Delta H$ - total runoff taking the losses into account [mm];

$H g_{z}$ - underground runoff reduced by the losses within a depression cone [mm];

$H p$ - surface runoff [mm];

$\mathrm{Hz}$ - discharge of water from the Lhoist Bukowa mine [mm];

$H n$ - tributary to the area of natural habitats within a depression cone [mm].

The calculated total runoff $(\Delta H)$ in two sections takes into account the underground runoff reduced with water loss within the cones $\left(\mathrm{Hg}_{z}\right)$, surface runoff $(H p)$, supply from the discharge of water from the Bukowa mine $(\mathrm{Hz})$ and the inflow of water to the area of natural habitats within the depression cone $(H n)$.

In further calculations there are two variants taken into consideration: an optimistic and a pessimistic one. The first one is identified with the highest total runoff in $\mathrm{mm}$ (calculated using the specific runoff), and the other - with the lowest runoff (Punzet method).

The underground runoff $\left(\mathrm{Hg}_{z}\right)$ was calculated on basis of the average minimal flow $(S N Q)$ determined by the two empirical methods discussed above. The higher value - calculated by the specific runoff method, was used to analyze the runoff in the optimistic variant and the 
lower one (by Byczkowski and Mandes method) - pessimistic. It is assumed that the surface runoff $(H p)$ makes the difference between the total runoff $(H c)$ and the underground runoff $\left(\mathrm{Hg}_{\mathrm{z}}\right)$.

Having taken into consideration the range of mine depression cones in subsequent stages of exploitation of deposits at Leśnica-Małogoszcz and Bukowa there was carried out a simulation of underground runoff at different levels of altitude $\left(\mathrm{Hg}_{z}\right)$ under the influence of mine depression cones. It was assumed that within each depression cone the groundwater charge of each stream will disappear, and it will occur in other parts of the basin. On this basis the weighted value of underground runoff rate from the catchment has been estimated. It will be highly spatially variable and dependent on the considered level of exploitation and the adopted variant of analysis (op- timistic, pessimistic). For example, the expected exploitation of the Małogoszcz mine at $+215 \mathrm{~m}$ a.s.l. will result in the absence of surface runoff within $11.4 \%$ of the Wrzosówka river catchment in cross-section of the Tory, and in the cross-section of Ujście $-23.1 \%$. The surface runoff rate will decrease here, respectively from 0.52 to 0.45 (Tory) and from 0.52 to 0.39 (Ujście). This means reducing the underground runoff $\left(\mathrm{Hg}_{z}\right)$ in the considered catchments to the level of: in an optimistic variant - $78.1 \mathrm{~mm}$ (Tory) and $68.0 \mathrm{~mm}$ (Ujście), and respectively a pessimistic one 64.2 and $53.4 \mathrm{~mm}$ (Table 4).

One of the components of the river water balance is also infiltration rate of river water within the boundaries of the predicted cone of depression. It will be small, because the lowering of the groundwater table in the marginal

TABLE 4. Results of runoff calculations from the Wrzosówka catchment including the impact of a depression cone of the Małogoszcz mine, at the level of exploitation of $+215 \mathrm{~m}$ a.s.l.

\begin{tabular}{|c|c|c|c|c|c|c|c|c|c|}
\hline \multirow{2}{*}{$\begin{array}{l}\text { Cross- } \\
\text {-section }\end{array}$} & \multirow{2}{*}{ Variant } & $H c$ & $\mathrm{~Hz}$ & $H g_{z}$ & $H p$ & $H n$ & $\Delta H$ & $H n h$ & $\Delta H-H n h$ \\
\hline & & \multicolumn{8}{|c|}{$\mathrm{mm}$} \\
\hline \multirow{2}{*}{ Tory } & optimistic & $170.3^{1}$ & $14.3^{\mathrm{A}}$ & $78.1^{1}$ & 82.1 & \multirow{2}{*}{0.3} & 174.2 & $92.2^{3}$ & +82.0 \\
\hline & pessimistic & $152.7^{2}$ & $14.3^{\mathrm{A}}$ & $64.2^{3}$ & 80.2 & & 158.4 & $112.2^{1}$ & +46.2 \\
\hline \multirow{2}{*}{ Ujście } & optimistic & $170.2^{1}$ & $14.3^{\mathrm{A}}$ & $68.0^{1}$ & 82.0 & \multirow{2}{*}{2.8} & 161.5 & $88.2^{3}$ & +73.3 \\
\hline & pessimistic & $150.4^{2}$ & $14.3^{\mathrm{A}}$ & $53.4^{3}$ & 81.0 & & 151.5 & $112.2^{1}$ & +39.3 \\
\hline
\end{tabular}

Hc - total runoff in the current conditions;

$H n h$ - hydrobiological inviolable runoff (by the method of specific runoff);

1 - calculated using the specific runoff method;

2 - calculated by Punzet method;

3 - calculated by Byczkowski and Mandes method;

A - the current value of pit dewatering of the Bukowa mine was adapted at a minimum level, i.e. $0.5 \mathrm{~m}^{3} \cdot \mathrm{min}^{-1}$ (Dokumentacja..., 2012b).

Other explanations as in equation (1). 
zone of cone of depression is usually very small (less than $1 \mathrm{~m}$ ). It has been assumed that its value is within the limits of computational error for other elements of the balance sheet and can be completely ignored in the calculations.

Currently, as a result of dewatering the Bukowa mine there occurs the water discharge into the Wrzosówka stream in the dimension of $0.5-1.0 \mathrm{~m}^{3} \cdot \mathrm{min}^{-1}$ (Dokumentacja..., 2012b). For the calculations there were two values adapted depending on the considered level of exploitation and a predicted variant of development of hydrogeological state. The volume of the water discharged was converted into runoff $(\mathrm{Hz})$, which is, respectively, 14.3 and $28.6 \mathrm{~mm}$. It is worth noting that the predicted volume of the discharges from the Bukowa mine, while reducing the exploitation, are still much higher than those adopted in the study (Dokumentacja..., 2012b), and then should not be discharged into the Wrzosówka stream, due to the high content of calcium carbonate which would cause excessive alkalinization of water and wetland habitats in the Wrzosówka river valley.

The analysis of the water needs of two wetlands was conducted by calculating their water supply $(\mathrm{Hn})$ necessary to maintain a good ecological status. It was assumed that this state will be adequate if the underground runoff from these areas, in the case of formation of mine depression cones, remains at the present level. The calculations indicate that to maintain the adequate soil moisture of wetland habitats above the Tory cross-section, which cover a small area within the mine depression cone (approx. 7 ha - exploitation at the Małogoszcz mine at $+215 \mathrm{~m}$ a.s.l., approx. $45 \mathrm{ha}-$ at the level of $+200 \mathrm{~m}$ a.s.1.), it is necessary in the first variant not more than $6,000 \mathrm{~m}^{3}$ of water per year, and in the second one approx. $37,000 \mathrm{~m}^{3}$. This corresponds with the runoff from the whole basin of the Tory cross-section -0.3 and $2.0 \mathrm{~mm}$ (Table 4). In turn, for the Ujście cross-section these values would be respectively: 64,000 and $95,000 \mathrm{~m}^{3}$ (2.8 and $4.2 \mathrm{~mm}$ ).

Subsequently, these results were related to the value of hydrobiological inviolable runoff (Hnh), which was determined in accordance with commonly accepted methodology (Kostrzewa, 1977, Witowski et al., 2001). On this basis the difference between the total runoff $(\Delta H)(\mathrm{mm})$ and inviolable runoff $(H n h)$ was determined. The positive values of the runoff obtained in this way indicate, that the water supplies in the Wrzosówka catchment, in the conditions of existing depression cones connected with the exploitation of deposits at different levels, will be sufficient to charge the endangered wetlands. The calculation results are shown in Tables 4-7. 
TABLE 5. Results of runoff calculations from the Wrzosówka catchment including the impact of a depression cone of the Małogoszcz mine, at the level of exploitation of $+200 \mathrm{~m}$ a.s.l.

\begin{tabular}{|c|c|c|c|c|c|c|c|c|c|}
\hline \multirow{2}{*}{$\begin{array}{l}\text { Cross- } \\
\text {-section }\end{array}$} & \multirow{2}{*}{ Variant } & $H c$ & $\mathrm{~Hz}$ & $H g_{z}$ & $H p$ & $H n$ & $\Delta H$ & $H n h$ & $\Delta H-H n h$ \\
\hline & & \multicolumn{8}{|c|}{$\mathrm{mm}$} \\
\hline \multirow{2}{*}{ Tory } & optimistic & $170.3^{1}$ & $14.3^{\mathrm{A}}$ & $57.5^{1}$ & 82.1 & \multirow{2}{*}{2.0} & 151.9 & $92.2^{3}$ & +59.7 \\
\hline & pessimistic & $152.7^{2}$ & $14.3^{\mathrm{A}}$ & $47.3^{3}$ & 80.2 & & 139.8 & $112.2^{1}$ & +27.6 \\
\hline \multirow{2}{*}{ Ujście } & optimistic & $170.2^{1}$ & $14.3^{\mathrm{A}}$ & $51.7^{1}$ & 82.0 & \multirow{2}{*}{4.2} & 143.8 & $88.2^{3}$ & +55.6 \\
\hline & pessimistic & $150.4^{2}$ & $14.3^{\mathrm{A}}$ & $40.7^{3}$ & 81.0 & & 131.8 & $112.2^{1}$ & +19.6 \\
\hline
\end{tabular}

Explanations as in equation (1).

TABLE 6. Results of runoff calculations from the Wrzosówka catchment including the impact of depression cones of the: Małogoszcz mine - level of exploitation $+215 \mathrm{~m}$ a.s.l. and Bukowa mine - level of exploitation $+220 \mathrm{~m}$ a.s.l.

\begin{tabular}{|c|c|c|c|c|c|c|c|c|c|}
\hline \multirow{2}{*}{$\begin{array}{l}\text { Cross- } \\
\text {-section }\end{array}$} & \multirow{2}{*}{ Variant } & $H c$ & $\mathrm{~Hz}$ & $H g_{z}$ & $H p$ & $H n$ & $\Delta H$ & Hnh & $\Delta H-H n h$ \\
\hline & & \multicolumn{8}{|c|}{$\mathrm{mm}$} \\
\hline \multirow{2}{*}{ Tory } & optimistic & $170.3^{1}$ & $28.6^{\mathrm{B}}$ & $33.1^{1}$ & 82.1 & \multirow{2}{*}{0.3} & 143.5 & $92.2^{3}$ & +51.3 \\
\hline & pessimistic & $152.7^{2}$ & $14.3^{\mathrm{A}}$ & $27.2^{3}$ & 80.2 & & 121.4 & $112.2^{1}$ & +9.2 \\
\hline \multirow{2}{*}{ Ujście } & optimistic & $170.2^{1}$ & $28.6^{\mathrm{B}}$ & $32.1^{1}$ & 82.0 & \multirow{2}{*}{2.8} & 139.9 & $88.2^{3}$ & +51.7 \\
\hline & pessimistic & $150.4^{2}$ & $14.3^{\mathrm{A}}$ & $25.3^{3}$ & 81.0 & & 117.8 & $112.2^{1}$ & +5.6 \\
\hline
\end{tabular}

Explanations as in equation (1).

TABLE 7. Results of runoff calculations from the Wrzosówka catchment including the impact of depression cones of the: Małogoszcz mine - level of exploitation $+200 \mathrm{~m}$ a.s.l. and Bukowa mine - level of exploitation $+200 \mathrm{~m}$ a.s.l.

\begin{tabular}{|c|c|c|c|c|c|c|c|c|c|}
\hline \multirow{2}{*}{$\begin{array}{l}\text { Cross- } \\
\text {-section }\end{array}$} & \multirow{2}{*}{ Variant } & $H c$ & $\mathrm{~Hz}$ & $H g_{z}$ & $H p$ & $H n$ & $\Delta H$ & $H n h$ & $\Delta H-H n h$ \\
\hline & & \multicolumn{8}{|c|}{$\mathrm{mm}$} \\
\hline \multirow{2}{*}{ Tory } & optimistic & $170.3^{1}$ & $28.6^{\mathrm{B}}$ & $22.3^{1}$ & 82.1 & \multirow{2}{*}{2.0} & 131.0 & $92.2^{3}$ & +38.8 \\
\hline & pessimistic & $152.7^{2}$ & $28.6^{\mathrm{B}}$ & $18.3^{3}$ & 80.2 & & 125.1 & $112.2^{1}$ & +12.9 \\
\hline \multirow{2}{*}{ Ujście } & optimistic & $170.2^{1}$ & $28.6^{\mathrm{B}}$ & $23.7^{1}$ & 82.0 & \multirow{2}{*}{4.2} & 130.1 & $88.2^{3}$ & +41.9 \\
\hline & pessimistic & $150.4^{2}$ & $28.6^{\mathrm{B}}$ & $18.7^{3}$ & 81.0 & & 124.1 & $112.2^{1}$ & +11.9 \\
\hline
\end{tabular}

B - the current value of pit dewatering of the Bukowa mine was adapted at a maximum level, i.e. $1.0 \mathrm{~m}^{3} \cdot \mathrm{min}^{-1}$ (Dokumentacja..., 2012b).

Other explanations as in equation (1).

The prediction of hydrological effects resulting from impact of mine depression cones on the water environment of the Wrzosówka catchment carried out in four variants, with particular emphasis on wetlands, showed that the optimistic variant the inviolable runoff will always be exceeded, and the surplus in the section of the Tory and Ujście cross-sections will range respectively from 38.8 to 82.0 and 41.9 to $73.3 \mathrm{~mm}$ (Tables 4-7). They can also take positive values in the situation of the absence of water discharge from the Bukowa mine, which 
may take place in the area. However, taking into account the results of previous hydrological analyzes of the Lososina drainage basin (Ciupa and Suligowski, 2011), we should keep in mind that the natural fluctuations of water resources in the area may have large amplitudes in both the annual cross-section and from year to year. In the pessimistic variant, the following values of runoff surplus in relation to the inviolable runoff were obtained: the cross-section of the Tory from 9.2 to $46.2 \mathrm{~mm}$ and of the Ujście from 11.9 to $39.3 \mathrm{~mm}$ (Tables 4-7). It should be noted, however, that the mine water discharges from Bukowa were adopted at the current level, and hydrogeological documentation (Dokumentacja..., 2012b) shows that in the future they may be even larger.

In order to preserve the existing wetlands with valuable natural habitats located within the depression cones of the Wrzosówka catchment area - in the conditions of existing here sufficient and documented water resources, environmental solutions have been suggested. The predicted water shortages here should be compensated by increasing the subsurface retention in these areas. It can be done by retaining part of the water outflowing the river channel, keeping the reserved flow and redirecting it to protected habitats. This would require the implementation of a simple and low-cost damming (threshold-riffle) in the Wrzosówka river bed and waterdrainage works (directional ditches) at the bottom of its valley (Pawlaczyk et al., 2001) and within the two analyzed wetlands. The deadline for completion of this work should be correlated with the exploitation of the Leśnica-Małogoszcz deposit at +215 and $+200 \mathrm{~m}$ a.s.l. and preceded by the measurements of the local monitoring system.

Construction of five threshold-riffles made of wood and stone is suggested, causing an increase of the water in the river channel to a certain level (Jędryka, 2007). This water should be distributed, through the area requiring protection of habitats, with gravity directional drainage ditches system, beginning above each threshold. There should diverge some side ditches from the main ditch every few dozen meters (Fig. 2).

The expected total length of the ditches should be about $5.5 \mathrm{~km}$ in variant I (level of exploitation of marl and limestone of Leśnica-Małogoszcz deposit $+215 \mathrm{~m}$ a.s.1.) and approx. 3.2 $\mathrm{km}$ in variant II (level of exploitation $+200 \mathrm{~m}$ a.s.1.). The main ditches in variant I would be the length of $2.8 \mathrm{~km}$, and $1.2 \mathrm{~km}$ and more in the second one. Supplying the wetlands with the system of the ditches will be done with unequal intensity, dependent, in large part, on surplus water exceeding the specified inviolable flow. The threshold-riffles should be located approx. $10 \mathrm{~cm}$ below the elevation of the surrounding terrain, so that there would be no flooding and stagnation of the water within these habitats. The constructions should have a 
slope of at least $1: 20$, which makes it possible for fish, amphibians and aquatic invertebrates to migrate upstream and effectively oxygenates water. Below and above the threshold-riffle, the strengthening of the banks should be made of natural materials in order to protect the edges and the threshold against erosion. In addition, the stone overhead of the threshold-riffle should be padded with geotextile.

The course of the irrigation ditches should be adapted to the morphology of the terrain, with an adequate slope and range of endangered habitats. The elevation of the bottom of the trenches, in the initial section must be higher than the elevation of the bottom of the bed. The locations of these objects are shown in Figure 2.

The effect of the suggested actions should be the local water table rising in the endangered habitats and maintaining it there at the required level. A full evaluation of the effectiveness of the proposed solutions will be possible only after 2-3 years of mine depression cones and irrigation system functioning in the area.

\section{CONCLUSIONS}

The multidirectional analysis of water resources conducted in the ungauged Wrzosówka catchment showed that in conditions of functioning a depression cone, connected with the exploitation at different levels of the Leśnica-Małogoszcz deposit, they will be sufficient to supply endangered wetlands with rare natural species.
Natural water resources defined here, along with water discharges from the Bukowa mine allow hydration of these habitats regardless of the elevation of exploitation of limestone and marl deposits at Leśnica-Małogoszcz.

The suggested solutions of an ecohydrological character - damming installations (e.g. threshold-riffle) in the Wrzosówka river bed, as well as irrigation ditches at the bottom of its valley within the currently existing wetlands, will be in favour compensation of the loss of water in the area due to expansion of a predicted depression cone.

Maintaing the proper water management in the Wrzosówka catchment, even in the conditions of the extensive exploitation of natural resources and the emergence of still deeper depression cones, will help maintain the wetland natural habitats at the bottom of its valley as well as its inviolable flow.

\section{REFERENCES}

BIERNAT T., CIUPA T., SULIGOWSKI R. 2004: Komentarz do Mapy Hydrograficznej w skali 1:50 000, arkusz M-34-41-B Piekoszów [Commentary on the Hydrographic Map of Poland in the scale 1:50 000, sheet M-34-41-B Piekoszów]. GUGiK, Warszawa.

BYCZKOWSKI A. 1996: Hydrologia [Hydrology], 2. Wyd. SGGW, Warszawa.

CHOIŃSKI A. 1978: Analiza zmian układu sieci wód powierzchniowych i wód podziemnych, w południowej części Konińskiego Zagłębia Wegglowego [Analysis of changes in the network of the surface water and groundwater in the southern part of Konin Coal Basin]. Badania Fizjograficzne nad Polską Zachodnią, ser. A. Geografia fizyczna 31: 33-55. 
CIUPA T., SULIGOWSKI R., BIERNAT T. 2011: Komentarz do Mapy Sozologicznej w skali 1:50 000, arkusz M-34-41-D Chęciny [Commentary on the Sozological Map of Poland in the scale 1:50 000, sheet M-34-41-D Chęciny]. GUGiK, Warszawa.

CIUPA T., SULIGOWSKI R. 2010: Wody powierzchniowe [Surface waters] In: A. Świercz (Ed.) Monografia Chęcińsko-Kieleckiego Parku Krajobrazowego. Wyd. UJK, Kielce: 118-136.

Dokumentacja hydrogeologiczna określająca warunki hydrogeologiczne w związku z odwodnieniem złoża margli i wapieni „Leśnica-Małogoszcz" do rzędnej +200 m n.p.m. [Hydrogeological documentation specifying the hydrogeological conditions in relation to dewatering of marl and limestone „Leśnica-Małogoszcz" to level +200 m a.s.1.] 2012a. AGH, Kraków.

Dokumentacja hydrogeologiczna określająca warunki hydrogeologiczne w związku z odwadnianiem złoża wapieni „Bukowa“ do rzędnej +220 m n.p.m. [Hydrogeological documentation specifying the hydrogeological conditions in relation to dewatering of limestone „Bukowa” to level $+220 \mathrm{~m}$ a.s.1.] 2012b. Stowarzyszenie Naukowe im. Stanisława Staszica, Kraków.

HERMAN G., KACZOROWSKI Z., MALICKI W., PRAŻAK J., SZCZEPAŃSKI J. 1991: Modelowa analiza wpływu odwodnień złóż surowców skalnych w Białym Zagłębiu na regionalne stosunki wodne [A model analysis of the impact of open-pit dewatering at the „Białe Zagłębie“ regional water relations]. In: V Ogólnopolskie Sympozjum Współczesne problemy hydrogeologii, Warszawa-Jachranka. Wyd. SGGW, Warszawa: 122-126.

JĘDRYKA E. 2007: Budowle wodne $\mathrm{z}$ naturalnych materiałów. Woda - Środowisko - Obszary Wiejskie 2b: 55-74.

JOŃCZYK I., STACHOWICZ Z., SZCZEPIŃSKI J. 2005: Dynamika rozwoju leja depresji BOT KWB Bełchatów SA w następstwie eksploatacji systemu odwadniania wgłębnego [Development of the cone of depression due to dewatering of the „Bełchatów” lignite mine]. Prace Naukowe Instytutu Górnictwa Politechniki Wrocławskiej: 112.

KOSTRZEWA H. 1977: Weryfikacja kryteriów i wielkości przepływu nienaruszalnego dla rzek Polski [Verification of the criteria and amounts of minimum acceptable flow for Polish rivers]. Materiały Badawcze IMGW, Gospodarka Wodna i Ochrona Wód, Warszawa.

MAKSYMIUK Z. 2002: Rozwój leja depresyjnego KWB Bełchatów i jego związek z budową geologiczną regionu [Development of the depression sink in the Brown Coal Mine „Bełchatów” and its relations to a geological structure]. In: T. Ciupa, E. Kupczyk, R. Suligowski [Eds]. Obieg wody w zmieniającym się środowisku [Water circulation in changing environment]. Prace Instytutu Geografii AŚ w Kielcach 7: 293-300.

MOTYKA J., CZOP M., JOŃCZYK W., STACHOWICZ Z., JOŃCZYK I., MARTYNIAK R. 2007: Wpływ głębokiej eksploatacji węgla brunatnego na zmiany środowiska wodnego w rejonie kopalni „Bełchatów” [Water environment impacts of the deep brown coal exploration in Bełchatów open-pit]. Górnictwo i Geoinżynieria 2: 477-487.

PAWLACZYK P., WOLEJKO L., JERMACZEK A., STAŃKO R. 2001: Poradnik ochrony mokradeł [Guide of wetland protection]. Wyd. Lubuski Klub Przyrodników, Świebodzin.

PRAŻAK J. 2012: Pozycja hydrodynamiczna i znaczenie gospodarcze dewońskich zbiorników wód podziemnych w Górach Świętokrzyskich [Position of hydrodynamic and economic significance of Devonian groundwater reservoirs in the Holy Cross Mountains]. Prace Państwowego Instytutu Geologicznego 198.

PRZEMYSKIA., PIWOWARSKI B., WERSTAK K., PRZEMYSKI P. 2012: Uwarunkowania przyrodnicze wokół kopalni odkrywkowej wapieni i margli jurajskich Leśnica-Małogoszcz (gm. Małogoszcz, woj. świętokrzyskie) [Natural conditions around the mine pit jurassic limestone and marl Leśnica-Małogoszcz]. Archiwum Lafarge Cement S.A., Małogoszcz.

RODZIK J., CIUPA T., JANICKI G., KOCIUBA W., TYC A., ZGŁOBICKI W. 2008: Współczesne przemiany rzeźby Wyżyn Polskich 
[Contemporary transformations of relief in Polish Uplands]. In: L. Starkel, A. Kostrzewski, A. Kotarba, K. Krzemień [Eds]. Współczesne przemiany rzeźby Polski [Contemporary transformations of relief in Poland]. Instytut Geografii i Gospodarki Przestrzennej UJ, Kraków.

SOŁTYSIK R. 2002: Geneza mokradeł Gór Świętokrzyskich i Niecki Nidziańskiej [Genesis of wetlands of the Holy Cross Mts. and Nida Basin]. Prace Instytutu Geografii AŚ w Kielcach 9.

STACHOWICZ Z., SZCZEPIŃSKI J. 2007: Ocena wpływu odwadniania przyszłej odkrywki „Piaski” KWB „Konin” SA na środowisko wodne [Impact assessment of the future "Piaski" open pit dewatering on the water environment]. Górnictwo i Geoinżynieria 2: $567-574$.

SULIGOWSKI R., KUPCZYK E., KASPRZYK A., KOŚLACZ R. 2009: Woda w środowisku przyrodniczym województwa świętokrzyskiego [Water in the natural environment and economic use of water resources in the Świętokrzyskie Voivodeship]. Instytut Geografii UJK, Kielce.

SZCZEPAŃSKI A. 1982: Prognoza wpływu głębokiej eksploatacji odkrywkowej surowców skalnych na warunki wodne południowo-zachodniej części Gór Świętokrzyskich [Forecast the impact of the deep open pit mining rock materials on water conditions in the south-western part of the Holy Cross Mts.]. Rocznik Świętokrzyski 10: 23-38.

SZCZEPAŃSKI A. 1987: Bezpośredni i pośredni wpływ odwadniania kopalń w Białym Zagłębiu na ilość i jakość wód poziomu dewońskiego [Direct and indirect impact of mine dewatering in the "Białe Zagłębie” on the quantity and quality of Devonian aquifer]. In: Ochrona i zanieczyszczenie wód podziemnych [Protection and pollution of groundwater]. Wrocław: 360-369.

WILK Z. 1999: Hydrogeologia górnicza w Polsce - wczoraj, dziś i jutro [Mining hydrogeology in Poland - past, present and future]. Biuletyn Państwowego Instytutu Geologicznego 388: 229-247.
WILK Z. (Ed.) 1990: Mapa przeobrażeń hydrogeologicznych pod wpływem działalności górnictwa w Polsce na tle warunków środowiskowych 1:500 000 [Map of hydrogeological transformations under the influence of mining activities in Poland against environmental conditions in the scale 1:500 000]. PIG, Warszawa.

WILK Z. (Ed.) 2003: Hydrogeologia polskich złóż kopalin i rejonów górniczych [Hydrogeology of mineral deposits and mining areas in Poland], 1. AGH, Kraków.

WILK Z., BOCHEŃSKA T. (Eds) 2003: Hydrogeologia polskich złóż kopalin i rejonów górniczych [Hydrogeology of mineral deposits and mining areas in Poland], 2. AGH, Kraków.

WILK Z., KULMA R. (Eds) 2004: Hydrogeologia polskich złóż kopalin i rejonów górniczych [Hydrogeology of mineral deposits and mining areas in Poland], 3. AGH, Kraków.

WITOWSKI K., FILIPKOWSKI A., GROMIEC M.J. 2001: Obliczanie przepływu nienaruszalnego. Poradnik [Calculation of the minimum acceptable flow. Guide]. IMGW, Warszawa.

Streszczenie: Możliwości zachowania terenów podmokłych wzasięgu lejów depresyjnych kopalni wapieni i margli Leśnica-Małogoszcz oraz Bukowa $w$ sytuacji pogłębiania poziomu eksploatacji. W wyniku powiększania głębokości eksploatacji surowców skalnych złoża margli i wapieni Leśnica-Małogoszcz (Pasmo Przedborsko-Małogoskie - województwo świętokrzyskie), najpierw do poziomu +215 m n.p.m., a następnie +200 m n.p.m., rozwinięciu ulegnie lej depresji. Może on zagrozić istnieniu obszarów podmokłych wchodzących w skład sieci Natura 2000, położonych w jego zasięgu. Podmokłości te występują w strefie przedprzełomowej rzeki Łososiny przez Grząby Bolmińskie i Wzgórza Gnieździskie, w ujściowym odcinku jej niekontrolowanego hydrometrycznie dopływu - Wrzosówki. W pracy wykazano możliwość zachowania obecnego stanu uwilgotnienia istniejących tu siedlisk naturowych, z uwzględnieniem charakterystyk ilościowych elementów składowych obiegu wody oraz uwarunkowań morfologicznych. Analiza zasobów wodnych 
wykazała, że w warunkach funkcjonującego leja depresyjnego będą one wystarczające do zasilania zagrożonych obszarów podmokłych i umożliwią ich nawodnienie. Zaproponowano również rozwiązania o charakterze ekohydrologicznym, które rekompensowałyby ubytki wody na tym terenie w obrębie leja depresyjnego kopalni odkrywkowej. Wymagałoby to wybudowania urządzeń piętrzących (np. próg-bystrotok) w korycie Wrzosówki oraz systemu rowów irygacyjnych w dnie jej doliny.
Stowa kluczowe: kopalnia odkrywkowa, lej depresyjny, tereny podmokłe, Małogoszcz

MS. received July 2014

\section{Authors' address:}

Tadeusz Ciupa, Roman Suligowski

Zakład Hydrologii i Geoinformacji

Instytut Geografii

Uniwersytet Jana Kochanowskiego w Kielcach ul. Świętokrzyska 15, 25-406 Kielce

Poland 